\title{
Casting Metal: Opera Studies after Humanism
}

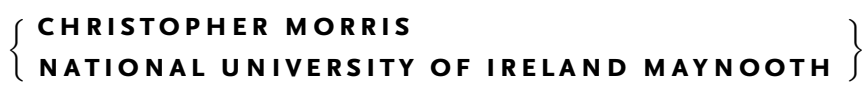

Among the calls for papers for the 2017 meeting of the Royal Music Association's Music and Philosophy Study Group at King's College London was the following for a themed session on the topic "Musical Nonhumans":

Frustrated with the limitations of late twentieth-century constructionism and hermeneutics, music scholars have recently begun to pay closer attention to the agency and materiality of musical "things." Aspects of the so-called new materialism are now evident in emerging research on the materiality of print sources, instrument technologies and media infrastructures, the material dimensions of subjective properties including identities, bodies and voices, and the ways that various aesthetic objects circulate and exert influence in the musical world. Most, however, treat the concern with musical things as a benign complement to traditional understandings of the musical object and its human use. In spite of increasing efforts in philosophy and media studies to revisit matters of political subjectivity and public formation in light of the material turn, the musicological categories of the human and the nonhuman remain largely undisturbed. ${ }^{\mathrm{I}}$

The claim that musicology has left intact the binary of human and nonhuman is couched with the qualifier "largely." If any fields of musical enquiry might justify this qualifier, they are those associated with music technology, sonic design, and contemporary music theater. The rise in prominence of installation-based performance, for example, has arguably refocused thinking on music by situating it as a sonic object partnered with physical objects and presented within the materially specific environs of venues such as public spaces, museums, and other non-traditional venues. Equally, music theater has long experimented with engagements between human performers and technologies that interact with body, voice, and instruments in ways that challenge conceptions of human subjectivity and the agency of the performer. If we can speak of posthumanism in music scholarship-that is, scholarship that problematizes human exceptionalism-it is to be found in the literature generated through and around these practices. ${ }^{2}$ It would be easy, though, to exaggerate the impact these perspectives have had on music scholarship more generally, 
and the authors of the RMA call for papers are no doubt justified in characterizing the wider field as they do. ${ }^{3}$

Rebecca Schneider has recently made similar observations with respect to performance and theater studies. She notes the rise and impact of time-based media and performance in galleries and other arts venues, of "curated" events, and even the emergence internationally of the "human book," a person borrowed for conversation and consultation. ${ }^{4}$ But if she detects the emergence of an important shift in practice, Schneider doubts whether these new conceptions of creative agency and its relationship to things have registered meaningfully in scholarship: "If living humans are not present to a performance themselves, then living humans must hide somewhere in the wings of actions, or be the ones to ultimately bear agential responsibility for the actions of objects or animals or plants... . Props, computers, projectors, pullies, dollies, light boards, costumes, cameras, and other paraphernalia of (co)production, curation, choreography, and display serve human artists, not the other way around." 5 The priorities and biases Schneider identifies in thinking about theater and performance prompt me to ask what "the other way around" might mean for opera studies.

Again, a qualification is in order. There is no question that scholars have begun to explore the agential capacity of opera's objects, not least in the pages of this journal, and I will consider the trajectories mapped out by some of this recent work. ${ }^{6}$ Part of what appears to have motivated this scholarship is a fascination with the abundant, not to say lavish, materiality of operatic practice, of props and sets, of costumes and makeup, of interior surfaces that reflect and absorb sound and light, of mouths, limbs, lungs, and vocal cords. What binds the gesturing arms of singers in Mary Ann Smart's Mimomania (2004) with the singing mouth shaped into an "O" in Lawrence Kramer's Opera and Modern Culture (2007) and with the embodied performance and spectatorship as presented in Linda and Michael Hutcheons's Bodily Charm: Living Opera (2000) is an attention to the materiality of the body in opera.? Running through these accounts is a decidedly un-Cartesian understanding of the operatic body as site of engagement - of collaboration-between the human, understood as subject or locus of agency, and flesh that is neither at the behest of that agency nor completely external to and separate from it. Such work offers a reminder, in other words, that a consideration of matter needs to begin already with the body and that the question of human agency is-at least in part-a question of the agentic capacity of the body.

Nor has attention to opera's objects ignored its historical dimensions. In fact, it has been accompanied both by a productive scrutiny of the history of operatic materials and by a reflexive engagement with the genealogy of materialism itself. As avid students of cultural history, opera studies scholars have long been drawn to the vivid discourse generated by opera: critical reception in the press and other first-hand accounts, memoirs, encyclopedia definitions of opera, and broader reflections on 
the aesthetics of opera. If this discursive trail has been shaped by local and historical contingencies, it registers a consistent fascination with, and provocation by, opera's materiality. What recent scholarship has begun to highlight is a historical recognition of the capacity of this materiality to challenge the limits of human agency. Drawing on Derrida, Bonnie Gordon has warned against perpetuating "presentist understandings of the divide between human and machine" at the expense of a more nuanced recognition of historical engagement with materiality, while Emily Dolan and John Tresch have highlighted the need to "rediscover music's machines" and push against a scholarly tradition of idealization and abstraction rooted in nineteenth-century thought. ${ }^{8}$ What informs these arguments is the contention that foregrounding operatic materiality and non-human agency is not a departure or revision, but an acknowledgment of something already evident in practice and discourse and, until recently, overlooked and underexamined in scholarship.

\section{Singing Particulants}

That opera studies poses this question at all owes something to the articulation of a shift in agency in opera away from the composer and librettist and toward the performer, especially the diva. Motivated in part by a radical re-evaluation of the gender dynamics of opera, and reinforced by the performative turn in scholarship more widely, this wave of performer- and gender-aware criticism, which began in the I990s, marked an important moment in opera studies' coming of age. Yet the centrality of human agency and the understanding of opera as centered on the externalization or realization of traditional forms of subjectivity is not questioned here. One article, itself very much enmeshed within the performative turn, did take these questions further. In "The Scandal of the Singing Body" of 2004, Michelle Duncan asks whether agency might extend to opera productions themselves. Duncan writes: "And though opera possesses neither individual cognition nor will, it is an artistic production that is phantasmagorically endowed with agency by those who are employed to create, to prepare and to execute it-to transform it into a (performative) event that acts. An operatic performance becomes a 'subject' through the specific social relations that bring it into being, that give it the agency to do something." 9 This is a provocative argument within an article that challenged a number of the concepts and assumptions - not least, presence-so central to theater and performance studies. But note the retention of the framework of human subjectivity ("performance becomes a 'subject") and of human initiative ("production ... is endowed with agency"). Moreover, this endowment is "phantasmagorical”-it is a projection, a product of the imagination. At the risk of summoning phantasmagoria of my own, I want to seize upon the implications of Duncan's proposal and extend it further: to consider whether agency in operatic practice might reside not only in 
the human, not only in those who are, as Duncan puts it, "employed to create, prepare and execute" opera.

I take my bearing in part from the work of Jane Bennett, which asks whether we might revisit the supposed inertness of non-organic matter and speak instead of a "vibrant matter," matter that is neither divinely infused nor a "life force" as in the nineteenth-century tradition of vitalism, but rather a "vitality intrinsic to materiality as such." Io Aware of the formidable weight of the (human) subject-centered tradition arrayed against such a proposition, Bennett laments the hubris of anthropocentrism and the limiting effect of what she regards as a myopic exclusion in thought, action, and politics: "I will emphasize, even overemphasize," she writes, "the agentic contributions of nonhuman forces (operating in nature, in the human body, and in human artifacts) in an attempt to counter the narcissistic reflex of human language and thought." "II Bennett draws on the work of Bruno Latour, and particularly his term "actant," defined as a source of action that can be either human or nonhuman; an actant is that which has efficacy, can do things, has sufficient coherence to make a difference, produce effects, alter the course of events. ${ }^{\text {I2 }}$ And not in isolation. As Bennett puts it: "While the smallest or simplest body or bit may indeed express a vital impetus, an actant never really acts alone. Its efficacy or agency always depends on the collaboration, cooperation, or interactive interference of many bodies and forces. A lot happens to the concept of agency once nonhuman things are figured less as social constructions and more as actors, and once humans themselves are assessed not as autonoms but as vital materialities." ${ }^{33}$ How might a consideration of these actants inflect our understanding of performance, of art, of artistic collaboration? These are among the questions posed in a recent issue of TDR: The Drama Review, edited by Rebecca Schneider and entitled "New Materialism and Performance." In her editorial introduction, Schneider playfully applies the concept of the human book to Bennett herself:

I imagine checking out Jane Bennett from the library for an afternoon. She and I might stand on the street corner outside the library.... She might tell me in oral form a story she narrates in writing in her book Vibrant Matter about some litter she encounters on the street that seems to her full of force, vitality, and agency independent of the human. As we talk, the story comes alive. She points out stray bits of litter at our feet, electric lights overhead, and the properties of weather that all swirl about us in a great, animate dance. Every single thing is participant in a grand live opera performed by the tiniest, singing particulants! It's a living drama with the life of the planet at stake, she tells me, composed in scenes of exquisite mundanity spun out across vast casts of molecules. Everything is vibrant! ${ }^{\mathrm{I} 4}$

On Schneider's vast stage, matter-agentic, vibrant, noisy—resounds as though a chorus in some grand operatic tableau. 


\section{The Headless Apprentice}

But what might it mean to take Schneider's opera metaphor and make it literal, to consider the materiality of actual operatic practice? To do this I turn to a specific production: Benvenuto Cellini of I838 (music by Berlioz), performed at the Salzburg Festival in 2007, broadcast on the German-language free-to air television channels ZDF and 3Sat, and released on DVD and Blu Ray in 20I0. I choose this production in part because it wears its theatricality_its operaticality-playfully on its sleeve. Benvenuto Cellini is an operatic text that invites a no-holds-barred approach to production: it's a lively, at times incoherent, fictionalization of the creation of Perseus with the Head of Medusa, a bronze statue cast by the sixteenth-century Florentine goldsmith and sculptor Benvenuto Cellini (I500-7I): the historical Cellini cast Perseus for Cosimo I de' Medici; in the opera the statue is commissioned by the Pope in exchange for a pardon from a charge of murder following a duel.

The director and designer of the production is Philipp Stölzl, a film, video, and stage director whose opera productions lavishly play on opera's own materiality and media identity by summoning and representing associated and contributing media. So, for example, his Der fliegende Holländer for Basel (2009) takes the opera's focus on a painting (the portrait of the Dutchman which fascinates Senta) as a cue for a gigantic framed tableau vivant from which characters emerge and to which they return, while his Pagliacci and Cavalleria rusticana for Salzburg (20I5) reflects on the displacement of opera by cinema in the Italian popular imagination by reimagining both operas as proto-cinema, complete with cinematic frames, lighting, black and white tints, and live video projections. The theme or Konzept of Benvenuto Cellini seems to be at once history (as though the opera's madcap take on Cellini's life and its projection onto him of Romantic concepts of genius were a cue to reconsider how the passage of time is negotiated) and materiality (Cellini's manipulation of material in his grand project). These themes coalesce and collide in a chaotic mise-enscène that takes visual cues from Fritz Lang's Metropolis-futuristic cityscapes, robots/cyborgs-but also channels the film's pastness as part of a wider retrofuturism in which historical features and aesthetics - vintage automobiles, art deco design - color the representation of a projected future. ${ }^{15}$

If there is a character in the production that embodies these themes, it is Ascanio, Cellini's loyal apprentice. A trouser role in the operatic text, Ascanio is here represented as a cyborg clearly modeled on Maria, the robot in Metropolis. But while Maria is machine from tip to toe, Ascanio is presented as part-human, part machine, her head covered in resistors and diodes on the back, her face human and feminized (see Fig. I). In "Mais qu'ai-je donc," the aria that opens act 3, Ascanio reflects on the predicament in which his/her master finds himself. Wanted for murder, Cellini will escape hanging only if he meets the Pope's condition that he complete the statue that very day. In an anticipation of "I whistle a happy tune," the 


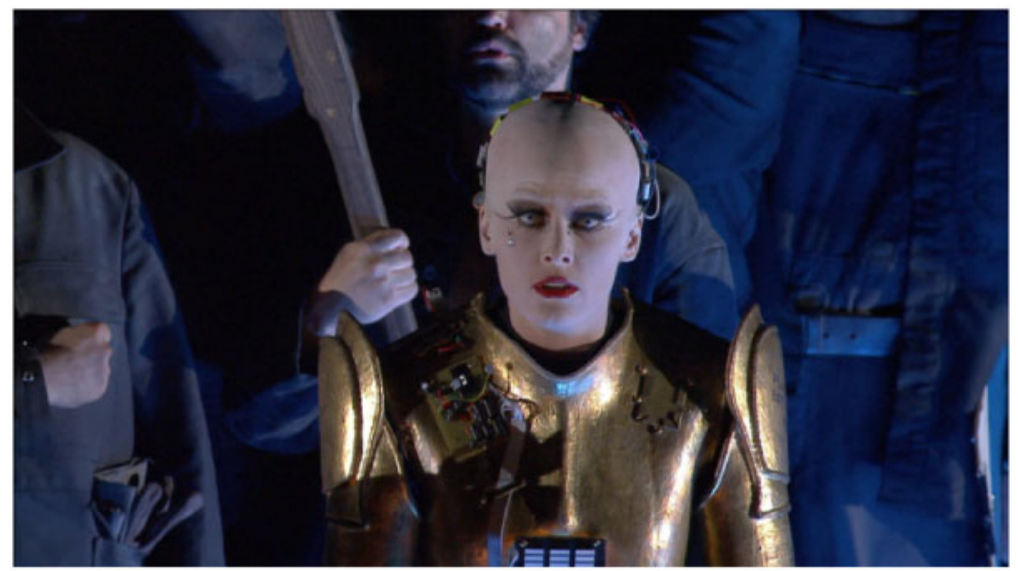

Figure 1 Benvenuto Cellini. Unitel Classica 2007.

classic number from The King and I, Ascanio declares that whenever s/he feels sad, s/he sings and laughs. Stölzl's staging, however, gives Ascanio more reason to cry: in a gesture unprompted by the plot but possibly inspired by the decapitated Medusa of Cellini's statue, Ascanio has been beheaded defending Cellini. Horrified and despairing, Cellini hands the lifeless head of Ascanio to the apprenctice's stillfunctioning body. Now the thickly tangled wires protruding from Ascanio's head resemble nothing so much as the snakes that take the place of locks of hair on the Medusa's head. Yet horror will quickly give way as the aria begins, for the severed head will go on to sing of ... singing and laughter (see Fig. 2).

It is a comic opera, after all, and even a severed head can't resist the animated and animating strains of Berlioz's aria. I want to consider the implications of this fragmented but singing body for our understanding of the role of things and of humans in opera. Writing on another singing head, that of the decapitated Orpheus in versions of the myth overlooked by opera, Carolyn Abbate presents the scene as a provocation to think about agency in operatic performance: "One cannot say how it sings, who is in charge, who is the source of the utterance." ${ }^{\text {'6 }}$ But where Abbate wants to read this agentic ambiguity as “uncanny," I want to understand Ascanio's singing head as a gesture that stages the limits of human agency not in the form of loss, mystery, or disorientation but as recognition of another possibility: that the anthropocentric impulse of humanism has blinded us to other animacies.

Bonnie Gordon likens the encounter of body, culture, and technology in the castrato with the notion of cyborg. Drawing on Donna Haraway's definition of the cyborg as "a fusion of the organic and the technical forged in particular historical, cultural practices," Gordon considers the implications of a cyborgean take on the castrato both for our understanding of history and for our engagement with the 


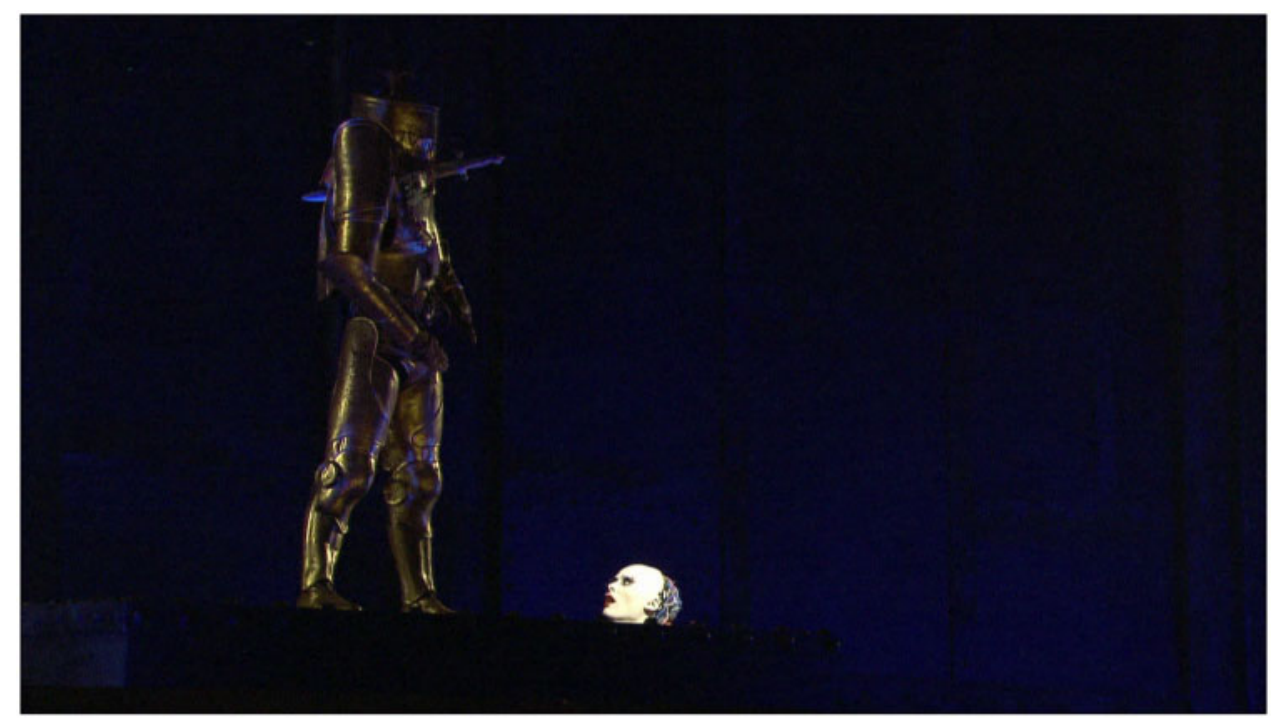

Figure 2 Benvenuto Cellini. Unitel Classica 2007.

contemporary resonance of the cyborg concept (a concept which generates a reaction ranging from excitement at its potential to real fear about what it may represent: the emancipatory potential of Haraway's cyborg manifesto has always seemed clouded by the realities of technological development). ${ }^{I 7}$ Stölzl stages the transhistorical encounter that Gordon imagines. We have a futuristic staging of an 1838 opera loosely projected onto a sixteenth-century artist. This kind of temporal juxtaposition is familiar enough in opera: my point here is that where Gordon challenges contemporary scholarship to get over its presentism and think about the cyborg (an encounter between technology and the body) as an encounter with a history, Stölzl stages that encounter, projecting the cyborg not onto the castrato but onto one of his relatives: the trouser role.

Like the castrato, the trouser role challenges gender norms, not in the disjunction between voice and body but between voice and body on the one hand, and theatrical representation on the other. This Ascanio figure juxtaposes gendered features and characteristics — note the lipstick, eyeliner, and false eyelashes — and yet the cyborg body resembles armor, as though Ascanio were not merely a sculptor's apprentice but a knight. In “Mais qu'ai-je donc," Stölzl's production presents us with a scene that almost traces in microcosm the body economy of opera: a spotlit fetishization of the head as location of the voice, happily independent of the torso. Yet a connection remains: as the body spins, so does the head; and in the middle section of the aria the torso tends to the head with contemplative gestures as though still united (see Fig. 3). And it's precisely in this ambiguity between independence and connection, wholeness and fragmentation, that the cyborg dynamic emerges. 


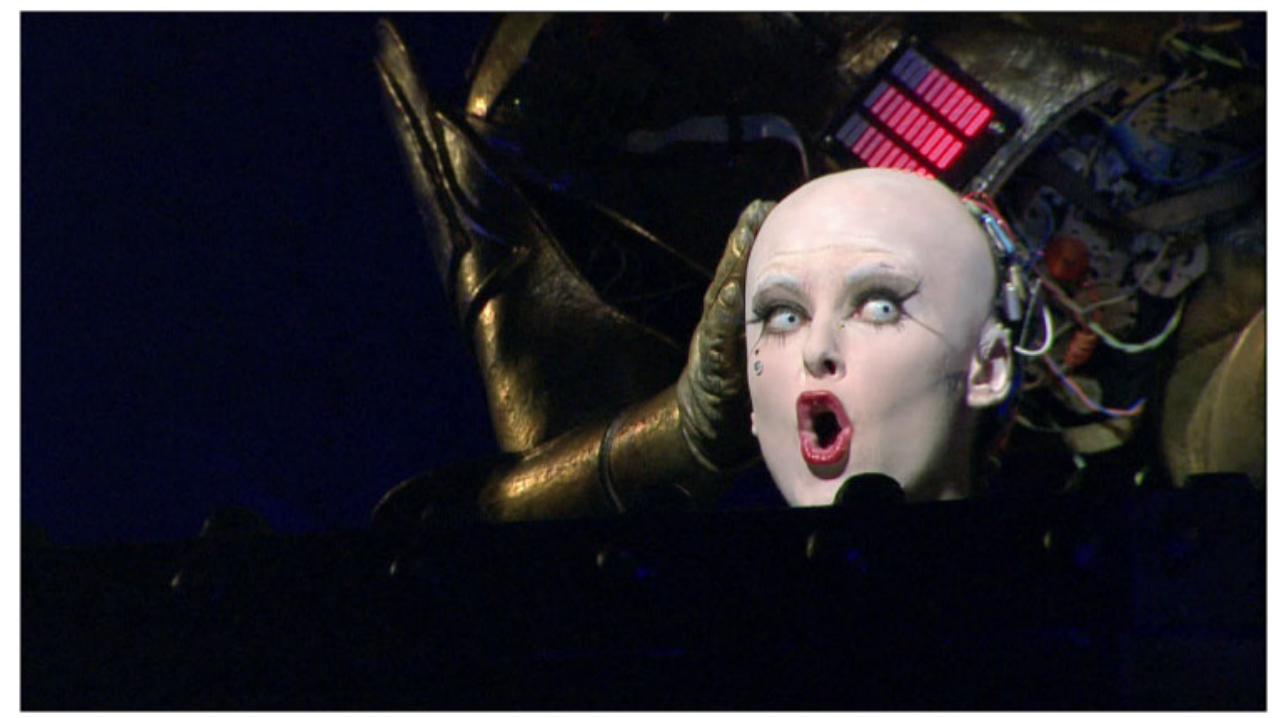

Figure 3 Benvenuto Cellini. Unitel Classica 2007.

What interests me most is the representation of agency. Who or what speaks and acts? For one, the body is split precisely according to its most obvious (one might say stereotypical) gender markers: the head, coded feminine in visual and sonic terms, is separated from the armor-clad torso, now bereft of precise gender markers but aligned with the masculine domain of knighthood, unless we are to imagine a Joan of Arc type figure. What are the gender implications of an envoiced but stranded feminized head and a gesturing but mute masculinized body? In a review of the DVD issue of the production, Daniel Albright detects in the Ascanio cyborg a transvestism not only of sex-he reminds us that Cellini at one point passionately kisses Ascanio, "in defiance of the rules of trousers roles"-but of animacy: isn't Ascanio's separated body, he asks, an avatar for Cellini (who, after all, faces the threat of hanging) ? ${ }^{\mathrm{I} 8}$

And what, Albright adds, are we to make of Ascanio's later gesture of throwing the metal cladding of his/her right forearm into the furnace when the supply of metal for the casting of Perseus runs low? ${ }^{19}$ In the libretto, by Barbier and de Wailly, Cellini pleads with his metal workers and associates to find every last piece of scrap and throw it into the furnace to complete the casting. In Stölzl's production, Ascanio's very personal, corporeal contribution to the statue seems to add a new dimension, making literal the phrase "to give one's right arm" and investing the metallic Perseus with cyborg material. Yet the libretto had already hinted at a bridging of the inert and the organic. In a hymn to their craft sung at the beginning of act 2 
and repeated at the end of the opera, the metalworkers characterize their materials in organic terms:

Les métaux, ces fleurs souterraines

Aux impérissables couleurs ...
Metals, those subterranean flowers

Of never-fading colours

But the metalworkers go further, investing gemstones with a life of their own:

Le jour, les diamants sommeillent, Le soleil éteint leurs splendeurs; Mais quand vient le soir, ils s'éveillent

Avec le chœur scintillant des étoiles leurs sœurs. . .

Honneur aux maittres ciseleurs!
By day, the diamonds slumber, The sun extinguishes their splendors; But when evening arrives, they awake With the glittering chorus of their sisters the stars ...

Hail to the master metalworkers!

If the craftsmen invest their materials with life, Stölzl's cyborg Ascanio invests in the casting process his/her own "flesh," itself already crafted and cast from molten metal. It's this kind of reciprocality that Bennett highlights when she presents the crystalline structure of metals as emblematic of a materiality that is anything but inert:

... metal is always metallurgical, always an alloy of the endeavors of many bodies, always something worked on by geological, biological, and often human agencies. And human metalworkers are themselves emergent effects of the vital materiality they work.... . The desire of the craftsperson to see what a metal can do, rather than the desire of the scientist to know what a metal is, enabled the former to discern a life in metal and thus, eventually, to collaborate more productively with it. ${ }^{20}$

The result of the collaboration-and contribution!-in Benvenuto Cellini is the casting of the statue of Perseus. That the statue might itself suggest animacy is not hinted at in the opera, but one historical observer adds a telling footnote. Although he did not attend the premiere of Benvenuto Cellini, Franz Liszt took the occasion as an opportunity to reflect on Berlioz's work as an extension and re-imagination of the artistry of the historical Benvenuto Cellini. In an evocative article dated November 30, I838, Liszt recalls lingering beneath Cellini's Perseus in the Piazza della Signoria on a Florentine evening: "The sight of that noble statue, enhanced by the night's spell, made an incomparably strong impression on me. I had often passed nearby without stopping to look at it closely, but this time I felt that I was detained by an invisible force. It seemed as if a mysterious voice was speaking, as if the statue's spirit was talking to me." ${ }^{2 \mathrm{I}}$ The theme of statues coming to life is an old literary motif and Liszt's experience shares obvious similarities to Florio's Venus in Eichendorff's “Das Marmorbild," Heine's "Florentinische Nächte," Mozart/Da Ponte's Commendatore in Don Giovanni, and Hoffmann's Olympia in Der 
Sandmann. ${ }^{22}$ The coming to life Liszt describes is hardly a recognition of the "vital materiality" Bennett has in mind. It is, rather, a re-animation of a familiar Romantic trope of the statue awakened, and the essay as a whole is ultimately a contribution to an idealist conception of art, with music as its clearest manifestation. Yet Liszt is far from disparaging of the materiality of sculpture: "In modern times and in the hands of a great artist, art takes on a perceptible form, it becomes plastic. The casting furnace is lit, the metal liquifies, it runs into the mold, and Perseus emerges fully armed holding Medusa's head aloft in his hand, the emblem of his victory. Glory to you, Cellini!"23 That this plastic exchange of forms should exert such a hold on Liszt and speak to him is testament to the reach of the Romantic imagination-and not least the imagination of a composer fascinated by the potential of "thematic variation"-but it also forges a telling link between the supposedly firm binaries of animate and inanimate, organic and inert. For Latour, it is precisely the defamiliarization triggered by art that offers scholars in other fields the opportunity to look again at matter and see "solid objects" recast "into the fluid states where their connections with humans may make sense." ${ }^{4}$ Derived from the Old Norse kasta (to throw), the English term "cast" has been applied to metalwork since at least the fifteenth century. Its adaptation, probably since the early eigthteenth century, to the assignment of roles in theatre appears to draw upon the suggestion of filling a mold. In Benvenuto Cellini, the two senses seem to merge again: the casting of metals is the casting of life, while metals can be understood as part of the opera's cast.

\section{The Level Meter}

Thus far I have considered Stölzl's production as a theatrical staging. Yet this overlooks an important mediating layer: my access to the production, and that of most if not all of my readers, comes not from attendance in the theater but from viewing the production on video. As I have argued elsewhere, it is not enough merely to view videos of opera stagings as transparent windows on a theatrical original. ${ }^{25}$ Rather, they are complex (re)mediations that inflect and color the work of spectator and researcher alike, and as such deserve attention in their own right. Yet attending to video as though it were a mediatized repackaging of an original and pure theatrical entity is equally unsatisfactory because it fails to register that remediation is not an afterthought but increasingly part and parcel of operatic production from the beginning. In part, this means challenging the entrenched view that opera is somehow mediatized through video when, in fact, opera on stage was already a media technology long before we associated the term with magnetized diaphragms and electron streams. It also means acknowledging the evolving role of screen media in contemporary stage practice, not only in the form of projection technologies deployed as part of a mise-en-scene, but also in the sense of an anticipation during 
production that the staging will be recorded and disseminated as video. Reflecting on these new practices, John Fulljames, former Associate Director of Opera at the Royal Opera House, stresses the increasing awareness of the importance and cultural value of video recording, not least because, as he puts it, the video will endure long beyond the limited runs on the stage. One of the implications, he adds, is that video direction is likely to be increasingly a consideration in stage production from the very beginning, just as lighting design in the opera house is now "intrinsic" to the creative process and possessed of a nuance and range akin to cinema and television. ${ }^{26}$ An experienced director of film and video, Stölzl mobilizes projections and cinematic imagery throughout the production of Benvenuto Cellini, but he also adds, in an interview, that cinema increasingly mediates engagement regardless of the medium: "the cultural perception of my generation is very strongly related to film no matter what." 27

Theatrical lighting and cinematic camerawork converge tellingly in Ascanio's aria when headshots - and they are now literally headshots - complement and reinforce the separation of head and body emphasized by the spot lighting: establishing shots enclose head and torso in the same frame, but close-ups isolate head and body, just as the pool of light on Ascanio's head emphasizes its isolation. It's precisely this fragmentation of bodies via media technology that Jennifer ParkerStarbuck associates with contemporary multimedia theater, which she dubs "cyborg theatre." In this theatrical practice, Parker-Starbuck writes, "what has previously been considered solely tool, prosthetic extension of the body, or system begins to claim concepts of agency." ${ }^{28}$ If the alignment of lighting and camerawork represents and reinforces the independent agency of Ascanio's head and torso, might it also claim agentic capacity in its own right? More than merely systems or tools, might these media technologies of light be actants? As Bennett puts it, "Worms, or electricity, or various gadgets, or fats, or metals, or stem cells are actants ... that, when in the right confederation with other physical and physiological bodies, can make big things happen." ${ }^{29}$

One "tool" attached to Ascanio's body offers to reflect tellingly on media technology and agency in the context of sound. Mounted on Ascanio's stomach is an LED level meter that visibly registers all the sounds produced by Ascanio and anyone or anything else in the vicinity. It is itself a form of remediation, one that registers sound precisely by remediating it as image. It might be reductive to suggest that opera itself is a kind of level meter, a device for rendering in visual terms a set of predefined sonic patterns. Yet I think there is a case to be made here in the limited sense that the combination of notational forms and performance conventions in music has been mobilized and institutionalized in the service of faithful reproduction, whereas the visualized forms of opera as theater are granted playful freedom and regarded as momentary realizations of an enduring text (which, to be fair, is not necessarily any different than other forms of text-based theater). Still, this analogy 
risks reducing the work of staging to a kind of mimesis when perhaps it can be credited with more latitude than this logic suggests.

More productive, I think, would be a consideration of the sonic and visual field that the level meter occupies and registers-or as Duncan reminds us, citing Shoshana Felman, the interaction of matter and energy recognized by contemporary physics: a "new type of materialism" in which the old distinctions between matter and energy are questioned. The voice, Duncan writes, "carries remnants of the body with it in a fluid interaction of matter and energy." ${ }^{\circ}$ Ascanio's level meter registers his/her own voice, which is here another's voice: a head sitting on the ground. It is as though the meter registers the field of matter and energy that binds the supposedly separate body parts. Consider, too, that the meter registers more than the sound of Ascanio's voice: it "hears" the orchestra, supposedly inaudible to the denizens of the operatic stage. And further still, it registers the sound from a body that is supposedly even less present to the operatic stage: the audience. Their applause fills Ascanio's meter in a lovely breach of the fourth wall, a performative gesture matched on stage when Ascanio's torso not only acknowledges the applause, but defers to and acknowledges his other body part, the head (see Fig. 4).

And doesn't this reaching out across the fourth wall point to how matter/energy might penetrate that fifth wall: the media wall that separates this auditorium from the audience for the video? In part, of course, the microphones placed around the auditorium and on the bodies of the singers register sound just as the level meter does, while the video cameras, with their light sensors, do the same for image. But to return to the field of matter/energy that binds mic to its sound sources and camera to its light sources, consider the transmitted light and sound that are registered by spectators seated in front of screens with headphone or in cinemas surrounded by speakers. Like the level meter, the spectators too are enfolded in a field that binds them to a supposedly remote and inaccessible space; and in the case of recorded video, a remote and inaccessible time. The point stressed by the scholarship of materialism is not the connection between spectators and performers but a broader inter-action and inter-connection between the forces and materials (including bodies) at play in this field and a reconsideration of the location of agency. As Diana Coole writes, "showing that agentic capacities are diffused across many different types of material entity, new materialists are able to decouple agency from humans while raising questions about the nature of life and of the place or status of the human within it."3I Not, then, "passive matter and form-giving agency" but a recognition of their "co-production." ${ }^{2}$ Not a harnessing of bodies in the service of machinic processes, but a recognition of the body as always already technological. Not an instrumental extension of human agency via technology, but an acknowledgment of the mutually dependent formation of the human and the technological. 


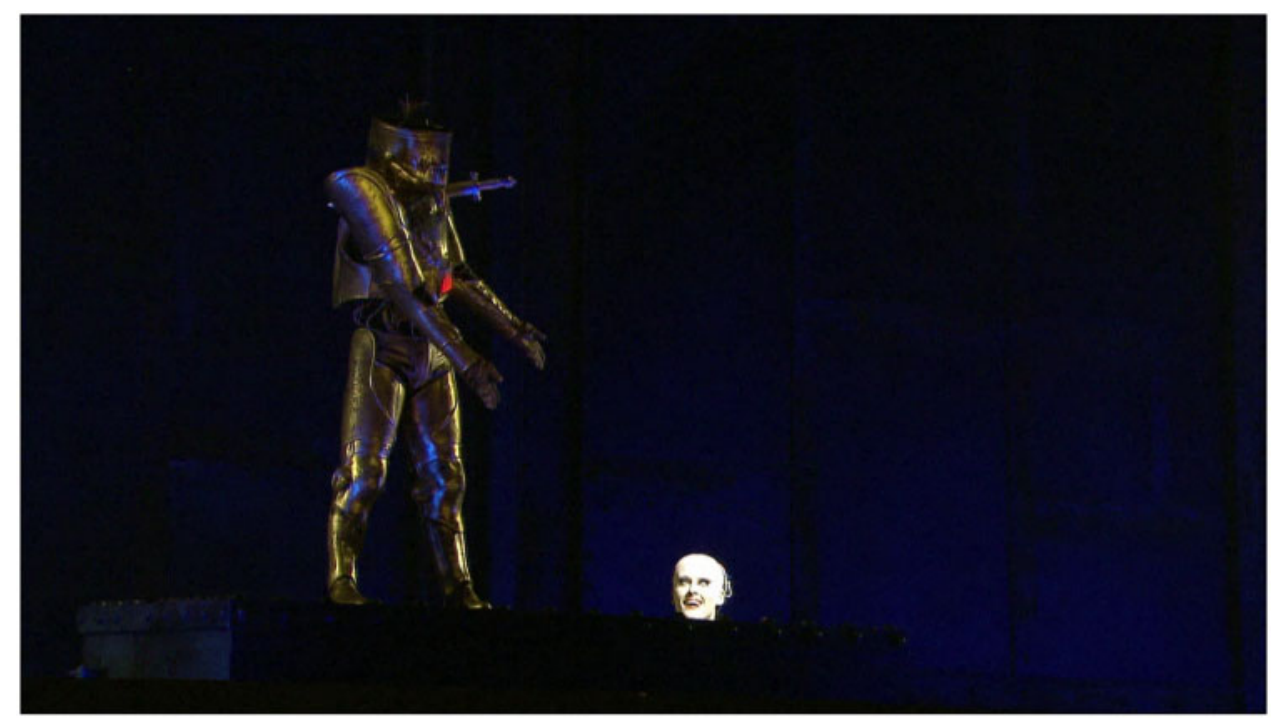

Figure 4 Benvenuto Cellini. Unitel Classica 2007.

\section{BECOMING CYBORG}

In conclusion, I want to look more closely at this idea of co-production and agentic capacity. In the context of opera, with its complex collaborative modes of practice, coproduction seems like an appropriate and familiar term, but almost always applied to human teamwork - at most the term is stretched to include institutional coproduction, where the institutions become stand-ins for teams of artists. But what about coproduction and collaboration with props, spaces, instruments, technologies of mediation and dissemination, or with bodies and voices understood in their material sense and not only as extensions of human agency?

In a making-of television documentary produced at the time of the broadcast of the Salzburg production, Kate Aldrich, the mezzo-soprano who plays Ascanio, discusses her role and demonstrates the make-up process involved. Aldrich says something very interesting at the end about the makeup and costume: "It helps put you in the robot thing. Once I'm in it it's hard not to move like this." 33 Perhaps this is the kind of explanation of method one might expect from an actor. What interests me, though, is the process of transformation that Aldrich describes, a process reminiscent of what Parker-Starbuck calls "becoming-cyborg." ${ }^{4}$ In Parker-Starbuck's reading, the cyborg is one of the means by which contemporary theater represents "the process of becoming post-human." 35 It is a process fraught with tension and danger, but she feels that technology is incorporated into multimedia post-dramatic theater in ways that encourage her to call it "cyborg theater" and that repeatedly demonstrate the capacity to acknowledge and properly problematize rather than 
smoothing over the tensions between body and technology, human and posthuman. Parker-Starbuck writes: "Cyborg theatre emerges out of the becomings, intersections, and figurations of incorporating and inscriptive practices that foreground the notion of embodiment." ${ }^{36}$ Note the Deleuzian emphasis here on becoming, on flux rather than ossified and supposedly stable states of being. This production of Benvenuto Cellini is not cyborg theater in the sense that Parker-Starbuck imagines it, but it does engage with the issues she associates with cyborg theater. Like cyborg theater, opera here becomes what Parker-Starbuck calls a "site for the examination and experimentation of the interconnected relationships between bodies and technologies." 37 Work has been done, bodies staged before audience, sounds and images disseminated over the airwaves and recorded.

What really intrigues me, though, is the place of the actor/singer in this process. What Aldrich describes, and the documentary presents, is preparation based on engagement with materials. It involves applications to and extensions of the body, and of learning to gesture with and through these applications. And finally, an exchange: the actor works with the materials; the materials transform the actor: "Once I'm in it it's hard not to move like this." Yes, this is theater, and Aldrich will return to the dressing room at the end of the night and remove the make-up. But all of this engagement and disengagement with materials comes to seem like a collaboration, a co-production. A tiny, though I would suggest telling, illustration: part of Aldrich's costume is a set of face jewels, tiny rhinestones applied to the skin, in this case in a teardrop pattern beneath the eyes. The rhinestones summon the words of the metalworkers of Benvenuto Cellini and their paean to precious stones: "By day, the diamonds slumber, / The sun extinguishes their splendors; / But when evening arrives, they awake / With the glittering chorus of their sisters the stars." Might the same be said of the face gems applied to Kate Aldrich? These (fake) diamonds, typically composed of acrylic polymers, are of course props: the symbolic value they accrue from the production means that they too are brought to life when evening arrives-brought to life as participants in theatrical play. What they purport to represent is diamonds, and just as the chorus of metalworkers imagines their awakening, so recent scholarship has reminded us of the repeated re-awakenings of matter. Confronting the ubiquitous characterization of stone as the most inert of inert materials (stone dead, stone cold, stone hearted, set in stone), Jeffrey Jerome Cohen highlights its animacy, its back-story of action: "Rising as mountains ... or burgeoning as gems, stone accrues in epochal strata, tumbles with glaciers, plunges deep under the sea in sheets, and ascends later as peaks veined with marine souvenirs. Mineralizing what had been organic life, compressing traces of multiple times into heterogeneous aggregates or metamorphic novelties, rock also bends like plastic so that ephemeral humans may sculpt a lithic whorl or devise a temple of a thousand years' duration." ${ }^{8}$ In this narrative the vibrant materiality of stone connects gems 
with buildings, one sculpted form to another, just as Cellini the craftsman engages intimately with stone and mineral, traversing from metalworking to sculpture.

And yet the costume rhinestones retain a strong indexical link to the outside world: a decoration on the face of Aldrich becomes a decoration on the face of Ascanio; a fake diamond becomes a fake diamond. In the stage world (the world Cellini inhabits), the rhinestone, like the false eyelashes and lipstick, is already theatrical, as though the cyborg Ascanio needed to bear strongly gendered marks as a reassuring sign of its humanity. The face gem, that is, retains its transparent falseness in its journey from dressing room table to stage; it appears on stage as itself (a knowingly fake adornment) just as the singer will "be" at once a character and, as the scholarship on divas has reminded us, a singer.

Refracting this play of self and other is another quality of theater and opera: its deeply collaborative nature. Here we might consider the collaboration implied in make-up and costume: "It helps put you in the robot thing." Aldrich's becomingcyborg, her time in costume and make-up, lasts, as she points out, an hour and half. Combined with removal of make-up and costume, the commitment is considerably longer than the time she spends on stage. She depends during this time not only on collaboration with humans but on an intimate engagement with materials, including a tiny rhinestone lifted from the makeup table and applied to skin with spirit gum or an adhesive backing (see Fig. 5). On stage, the rhinestone is illuminated and "awakens," like the "glittering chorus" of props and lights arrayed on and above the stage. Then, in the wake of the performance, removal, darkness, and slumber, perhaps to come alive again at the next performance or find itself discarded and replaced by another.

I take imaginative license here, admittedly, but the recent scholarly re-evaluation of materialism invites us to seize upon these projections and ask new questions, consider new possibilities. What, the new materialism asks, if things are not so inert, if agency is not utterly confined to the human? Reflecting on the "thingness" of Achilles' shield in Homer's Iliad, Bill Brown wonders if this recent scholarship on materialism, arising largely from political science and set against a modern anthropocentric tradition, is really so new. What, he asks, if "the poem does not acknowledge our more modern convictions about the difference between the animate and inanimate, subject and object, persons and things?"39 Schneider makes a similar point when she compares the anthropocentric thinking she detects in performance theory with performance practice: "Even as we are now expanding the realm of liveness beyond actors to theater's materials_-props, sets, lights, sound, makeup, and all the backstage machinery supporting the fretting and strutting about-haven't theater practitioners long recognized their objects and affects as actants?"4० Schneider's admonition to scholars in performance and theater studies to, as it were, get with the program might be directed at opera studies. Already likened in the nineteenth century to a machine-and earlier than that, as Gordon shows- 


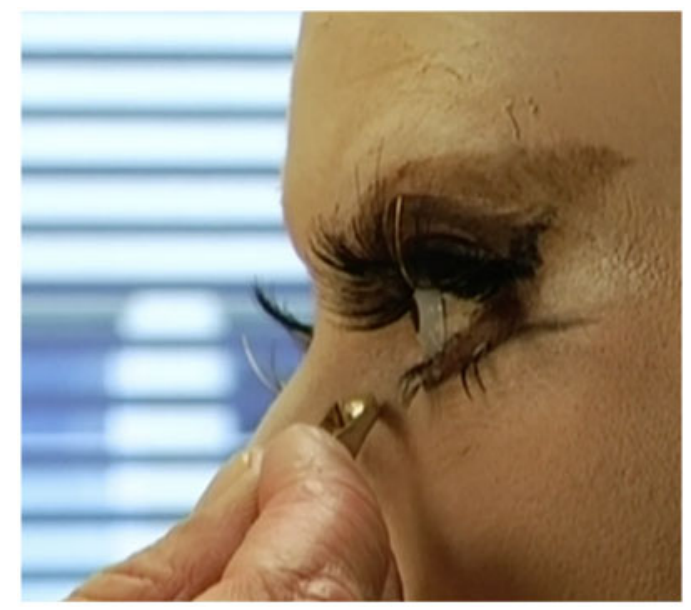

Figure 5. Talking Benvenuto Cellini. Unitel Classica 2007.

opera has long been understood in material terms that seem to transgress and exceed the anthropocentric model of artistic creativity as human mobilization of dead matter into living forms. As Dolan and Tresch argue, the practices and discourse of the Parisian "opera machine" of the I83os suggests an attempt to overcome "the simplistic dualism that opposes spirit and matter" with a more nuanced understanding of the tension that attends the encounter of the human with the material. ${ }^{4 \mathrm{I}}$

Yet these dualisms persist, evident still, as Dolan and Tresch observe, in musicology's "abstract, ideal conception of music." ${ }^{2}$ How might these encounters be reframed? How might the flattening notion of living human agency mechanized and mortified by inert materials and forces be challenged? We might begin by accepting Gordon's invitation to think about the limits of the human outside a narrow understanding of technology. Jonathan Sterne voices similar concerns when he writes: "When we focus on the gadgets in the diva's hands and ears, or the gadgets that put the diva in the hands and ears of her audience, we risk forgetting the tremendous artifice necessary for that first bit of breath that constitutes the onset of the first note that we hear sung, and the last little ringing bits of decay in our ears, or in our memories." ${ }^{3}$ We need to think about opera as always-already technological and liberated from the narrow and confining understanding of performance as an original, present, and irrecoverable happening. When Bennett situates actants within a field she terms "distributive agency" — a field that includes humans and non-humans, bodies and other matter — she could be describing the richly complex and collaborative form of operatic production, present and past. ${ }^{44}$

This historical "retroaction" will be meaningful if it is matched by an engagement with the questions raised by the new materialism, by a consideration of 
creative practice as a collaboration or networking of agents human and non-human, organic and inorganic. This is no defense of "de-humanization," still less an apology for technological determinism or a dismissal of historical or contemporary concerns about the dangers of technology unharnessed. Rather, it asks where agency lies and questions its confinement to body and mind, to creative spirit and genius, those humanist guarantors of efficacy. Addressing the phenomenon of Wagnerism and its potential to delineate the limits of human agency, Gary Tomlinson argues that traditional notions of "intersubjectivity" need to be expanded and liberated from the "narrow," humanist, and largely linguistic form it has assumed in structuralist and poststrucuralist thought. What it might now suggest is something more radical: "Intersubject names something broader than a social constitution of entities subsequently cast into the illusions and dilemmas of identity and individuality. It denotes the impossibility, determined by the widest biological and ecological conditions, of monadic subjectivity as such." ${ }^{45}$ At stake, then, is the identification of the limits of "human particularity" and, for Tomlinson, it is precisely the mobilization of music, words, and stage in music drama that vividly confronts us with those limits. ${ }^{46}$

If we believe that opera is exceptional in its capacity to generate and absorb networks of collaboration and co-production, to disseminate sounds and images across media both live and recorded, to foreground but then distend presence, then we will at least have opened up new paths of inquiry into one genre (or is it a medium?the ambiguity is telling). But these qualities depend upon, and in turn generate, an economy of meaning and materiality that spans generic borders. As opera studies continues to map "opera" as a discursive, ideational and affective field that reaches far beyond the opera house, far before and after the premiere, the particulars of opera begin to seem less particular and more emebedded, more distributed, more interdependent. In this reading opera is instructive and exemplary in ways that have wider currency for the study of performance, the role of materiality in performance, and the limits of the human.

\section{NOTES}

Christopher Morris is Professor of Music at the National University of Ireland Maynooth. He is author of Modernism and the Cult of Mountains: Music, Opera, Cinema (Farnham: Ashgate, 2012), as well as chapters and articles on opera and film-music topics. Recent publications include "The Deadness of Live Opera," in Performing Arts in Transition: Moving between Media, ed. Susanne Foellmer, Maria Katharina Schmidt, Cornelia Schmitz (New York:

Routledge, 2019), 126-39. With Joseph Attard, he recently co-edited an issue of Opera Quarterly (34/4) devoted to opera cinecasts.

1. "Musical Nonhumans," Call for Papers, Music and Philosophy Study Group, King's
College London, July 13-14, 2017; http://musicandphilosophy.ac.uk/theme2017nonhumans/

2. See, for example, Eric Salzman and Thomas Desi, The New Music Theater: Seeing the Voice, Hearing the Body (Oxford: Oxford University Press, 2008); Pieter Verstraete, "The Frequency of Imagination: Auditory Distress and Aurality in Contemporary Music Theatre" (PhD diss., University of Amsterdam, 2009); The Legacy of Opera: Reading Music Theatre as Experience and Performance, ed. Dominic Symonds and Pamela Karantonis (Amsterdam: Rodopi, 2013); Jelena Novák, Postopera: Reinventing the Voice-Body (Farnham: Ashgate, 2015); Voice Studies: Critical Approaches to Process, 
Performance and Experience, ed. Konstantinos Thomaidis and Ben Macpherson (New York: Routledge, 2015).

3. For an assessment of the dearth of scholarship on posthumanism and popular music, see Justin Adams Burton, Posthuman Rap (New York: Oxford University Press, 2017), 38.

4. See http://humanlibrary.org.

5. Rebecca Schneider, "New Materialisms and Performance Studies," TDR: The Drama Review 59/4 (2015; T228): 7-17; 9-10.

6. Cormac Newark, "Metaphors for Meyerbeer," Journal of the Royal Musical Association 127/1 (2002): 23-43. Technology and the Diva: Sopranos, Opera, and Media from Romanticism to the Digital Age, ed. Karen Henson (Cambridge: Cambridge University Press, 2016). Bonnie Gordon, "The Castrato Meets the Cyborg," Opera Quarterly 27/1 (2011): 94-122. Emily Dolan and John Tresch, "A Sublime Invasion: Meyerbeer, Balzac and the Opera Machine," Opera Quarterly 27/1 (2011): 4-31.

7. Mary Ann Smart, Mimomania: Music and Gesture in Nineteenth-Century Opera (Berkeley: University of California Press, 2004); Lawrence Kramer, Opera and Modern Culture: Wagner and Strauss (Berkeley: University of California Press, 2004), 222-24; Linda Hutcheon and Michael Hutcheon, Bodily Charm: Living Opera (Lincoln: University of Nebraska Press, 2000).

8. Gordon, "The Castrato Meets the Cyborg," 118; Dolan and Tresch, "A Sublime Invasion," 26-27.

9. Michelle Duncan, "The Operatic Scandal of the Singing Body: Voice, Presence, Performativity," Cambridge Opera Journal 16/3 (2004): 283-306; 300-301.

10. Jane Bennett, Vibrant Matter: A Political Ecology of Things (Durham, NC: Duke University Press, 2010), xvi.

11. Ibid.

12. Bruno Latour, Reassembling the Social: An Introduction to Actor-Network-Theory (New York: Oxford University Press, 2005).

13. Bennett, Vibrant Matter, 21.

14. Schneider, "New Materialisms and Performance Studies," 12.

15. Another retro-futurist city, the Gotham of the Batman comics and films, clearly surfaces here too in the artwork of the production's cityscapes.

16. Carolyn Abbate, In Search of Opera (Princeton: Princeton University Press, 2001), 5.

17. Donna Haraway, "A Cyborg Manifesto: Science, Technology, and Socialist-Feminism in the Late Twentieth Century," in Simians, Cyborgs and Women: The Reinvention of Nature (New York: Routledge, 1991), 149. Cited in Gordon, "The Castrato Meets the Cyborg," 114.

18. Daniel Albright, DVD review, Opera Today, 21 May 2011; http://www.operatoday.com/ content/2011/05/benvenuto_celli.php

19. Ibid.

20. Bennett, Vital Materialism, 60.

21. Franz Liszt, "The Perseus of Benvenuto Cellini," November 30, 1838, Gazette musicale (Jan. 13, 1839): 14-15; 14. Translated in Franz Liszt, An Artist's Journey, trans. Charles Suttoni (Chicago: University of Chicago Press, 1989), 153.

22. Liszt's nocturnal encounter with a statue recalls Heine's "Florentinische Nächte," published in his Salon III in 1837, a year earlier than Liszt's essay. In Heine's novel fragment, the protagonist Maximilian recalls his own dreamlike encounter with a Florentine statue at night. 23. Liszt, "The Perseus of Benvenuto Cellini," 153.

24. Latour, Reassembling the Social, 82.

25. See Christopher Morris, "Digital Diva: Opera on Video," Opera Quarterly 26/1 (2010): 96-119.

26. Joseph Attard, “'Opera Cinema, the Modern Gesamtkunstwerk?': Jonathan Haswell, John Fulljames, and Corinne Winters in Conversation with Eleonora Sammartino," Opera Quarterly 34/4 (2018): 343-54; 344.

27. Philipp Stölzl, interview in program booklet, Salzbuger Festspiele (August 2007), 26. 28. Jennifer Parker-Starbuck, Cyborg Theatre: Corporeal/Technological Intersections in Multimedia Performance (Basingstoke: Palgrave Macmillan, 2011), 40-41.

29. Bennett, Vital Materiality, 94.

30. Duncan, "The Scandal of the Singing Body," 303.

31. Diana Coole, "Agentic Capacities and Capacious Historical Materialism: Thinking with New Materialisms in the Political Sciences," Millennium: Journal of International Studies 41/3 (2013): 451-69; 457.

32. Ibid.

33. Talking Benvenuto Cellini (Unitel Classica), broadcast August 2007.

34. Parker-Starbuck, Cyborg Theater, 16.

35. Ibid., 15.

36. Ibid., 16.

37. Ibid., xiv.

38. Jeffrey Jerome Cohen, Stone: An Ecology of the Inhuman (Minneapolis: University of Minnesota Press, 2015), 84.

39. Bill Brown, Other Things (Chicago: University of Chicago Press, 2015), 3. For more on Brown's "things" in opera, see Alessandra 
Campana and Christopher Morris, "Puccini's Things: Materials and Media in I trittico," in Giacomo Puccini and His World, ed. Emanuele Senici and Arman Schwartz(Princeton: Princeton University Press, 2016), 133-57; 148-49.

40. Schneider, "New Materialisms," 14.

41. Dolan and Tresch, "A Sublime Invasion," 5.

42. Ibid., 26-27.

43. Jonathan Sterne, "Afterword: Opera,

Media, Technicity," in Henson, Technology and the Diva, 159-164; 164. See also Christopher Morris, "The Mute Stones Sing: Rigoletto Live from Mantua," TDR: The Drama Review 59/4 (2015; T228): 51-66; 63-64.

44. Bennett, Vibrant Matter, 21.
45. Gary Tomlinson, "Parahuman Wagnerism," Opera Quarterly 29/3-4 (2013): 186-202; 199.

46. For Tomlinson, these are questions provoked in unique ways by the encounter with Wagnerian music drama, an encounter that depends, in turn, on something unique about music and its capacity to challenge interpretation in its traditional guises. At the same time, Tomlinson problematizes the terms "Wagner" and "Wagnerism," and I am persuaded by this reevaluative move, and by the Wagnerian disavowal of the term "opera," to question these claims to exceptionalism and understand music drama precisely as operatic. See Tomlinson, "Parahuman Wagnerism," 201-202. 